\title{
SEASONAL VARIATION IN THE DENSITY OF THE MACROPHYTE Scirpus cubensis POEPP \& KUNTH (CYPERACEAE) IN THE LAGOA DO INFERNÃO, STATE OF SÃO PAULO, BRAZIL
}

\author{
M.L.M. Pompêo, V. Moschini-Carlos \\ Departamento de Zoologia, Instituto de Biociências, UNESP, C.P. 502, 18618-000 Botucatu - SP, Brazil
}

Key words: macrophyte, density. Scirpus cubensis

Palabras clave: macrbfitos, densidad, Scirpus cubensis.

\begin{abstract}
This paper deals with the seasonal density dynamics of the macrophyte Scirpus cubensis Poepp \& Kunth (Cyperaceae) in the Lagoa do Infernão, a lake marginal to the Mogi-Guaçu river, State of São Paulo, Brazil. Seasonal density dynamics of the macrophyte were studied in permanent plots of I m length by $25 \mathrm{~cm}$ width, divided into four subplots of $25 \times 25 \mathrm{~cm}$. An individual of S. cubensis was defined as an independent morphological unit arising from a rhizome node. Seasonal variation in density, with a range from $135.52 \pm$ 171.52 to $270.00 \pm 196.00$ ind. $\mathrm{m}^{-2}$, is related to the drought and flood conditions to which the lake is subject. Analysis of data also suggests that 12 sample units are significant for assessment of population density. Aspects of the macrophytes sampling are also discussed.
\end{abstract}

\section{INTRODUCTION}

Geological, hydrological and climatological conditions in tropical regions are favorable to the occurrence of areas liable to flooding (ESTEVES, 1988). The dynamic equilibrium in these areas often coincides with fluctuations in water level, leading to a "pulse stability" (ODUM, 1971). JUNK et al. (1989) the flood pulse to be the force largely responsible for the existence of systems of rivers with related to flood-liable areas, and for their productivity and interactions. Flood-liable areas are considered to be highly productive, and their macrophytes are a very important component in the trophic level.

The various macrophyte species which occur in flood-liable areas are not distributed at random; each one has its microhabitats, especially on flood gradients. The plant communities of aquatic environments are formed by a characteristic assemblage of species, in equilibrium in terms of their numbers and abundance, and occupying relatively homogeneous sites (BEST, 1988).

The difficulties which explain the shortage of structural studies of macrophyte communities are principally related to analytical methods (HENRIQUES et al., 1988). It is most important that the right methods should be selected for taking samples specific to each type of community, and that sampling should be carried out with great care so as to ensure accurate and useful results (BARBOUR et al., 1987).

The aim of this work is to analyze the seasonal density dynamics of the emergent macrophyte Scirpus cubensis Poepp \& Kunth (Cyperaceae) in the lake known as the Lagoa do Infernão, State of São Paulo, Brazil. According to GREIGSMITH (1983), unit counts for plants may be regarded as a basis for indirect estimate of biomass, with the great advantage that they do not involve destruction of the vegetation. Aspects of the sampling of macrophytes are also discussed.

\section{THE STUDY AREA}

The work underlying this paper was carried out in the Lagoa do Infernão, a lake marginal to the Mogi-Guaçu river and a component part of the Jatai Ecological Station, State of São Paulo, Brazil. The lake lies at $21^{\circ} 33^{\prime}$ S. $47^{\circ} 51^{\prime} \mathrm{W}$ (SANTOS \& MOZETO, 1992). It is small and shallow, with an average depth of $2.1 \mathrm{~m}$ and an area of 3.05 ha. (COUTINHO, 1989), and is horseshoe-shaped (fig. I) due to the continuous processes of'erosion and sedimentation which cut off the meanders of the river (ESTEVES, 1988).

The marginal region of the lake is characterized by Panicum pernambucensis, rooted in the sediment, and then by a floating 
mat made up mostly of Scirpus cubensis. Further out towards the limnetic region the floating macrophyte Eichhornia azurea occurs, followed by the submerged Cabomba pihauyensis (MOSCHINI-CARLOS, 1991).

The sigmatist method of Braun-Blanquet (MOSCHINICARLOS, 1991) and the seasonal variation in biomass (MOSCHINI-CARLOS et al., 1993) suggest that the plant association dominated by S. cubensis is homogeneous throughout the Lagoa do Infernão.

Through weather data - rainfall and air temperature CAVALHEIRO et al. (1990) and TOLEDO FILHO (1984) have established two quite distinct seasons for the study region. One is rainy, with higher temperatures and rainfall between November and April; the other is dry, with lower temperatures and rainfall between May and October. The hydrology of the Lagoa do Inferno is thus characterized by fluctuations of water level in the Mogi-Guaçu river; annual patterns involve cycles of flooding and drought.

In the study period occurred seasonal variation in precipitation from April to September 1989 and from April to May 1990 rainfall was low (fig. 2), varying from 21.0 to $51.0 \mathrm{~mm}$. From October 1989 to March 1990 rainfall was much higher, varying from 141.99 to $246.9 \mathrm{~mm}$.
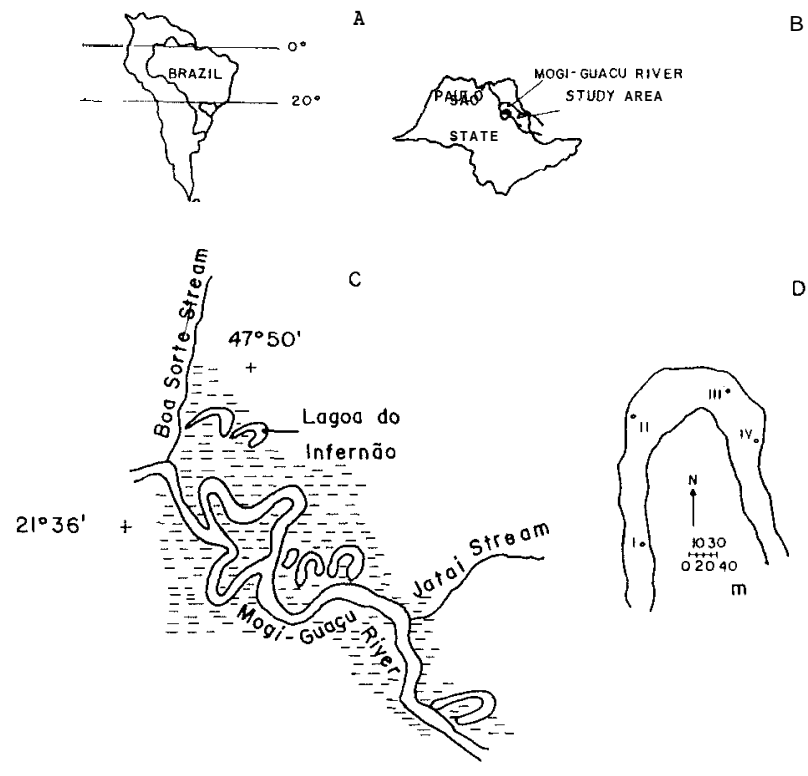

FIGURE I. Study area with location of the collecting sites $(\cdot)$ at the Lagoa do Infernão.

FIGURA 1. Área de muestreo en la Lagoa do Infernão $(\bullet)$.

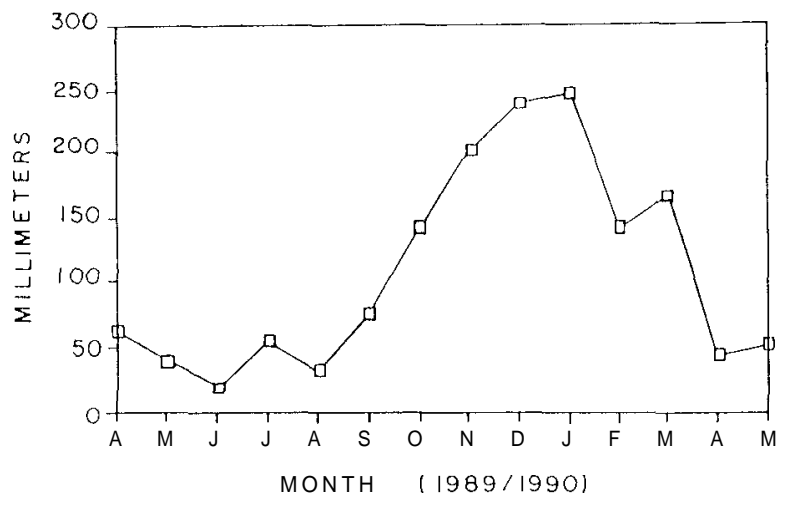

FIGURE 2 Seasonal differences in rainfall (monthly totals).

FIGURA 2. Diferencias estacionales en la época de lluvias, (totales mensuales).

\section{MATERIAL AND METHODS}

Scirpus cubensis (Cyperaceae) is widely distributed in tropical America and Africa. The macrophyte is perennial, and occurs rooted in sediment or attached to a floating substrate (COOK, 1974), as observed in Lagoa do Infernão. Leaves, fertile branches and roots arise from the nodes of the rhizome. For the purposes of the present work and for study of the density dynamics of the population, an individual is here regarded as an independent morphological unit arising from a rhizome node.

Two permanent plots, perpendicular to the shore and about 2 $\mathrm{m}$ apart, were established in the middle of each stand dominated by S. cubensis. Each plot was I m length by $25 \mathrm{~cm}$ width, and was divided into four sub-areas of $25 \times 25 \mathrm{~cm}$, each considered as a sampling unit. Four stands were selected, to cover the entire length of the lake (fig. 1), and plant density was measured at monthly intervals from April 1989 to May 1990.

Sampling units were grouped at random and cumulatively, to form 8 samples of 4, 8,12,16,20, 24, 28 and 32 units (MATTEUCCI \& COLMA, 1982). Averages, standard deviation, coefficients of variation and variance in average (obtained from the ratio $S^{2} / n$ where $S^{2}$ is the sample variance and $n$ is the number of sample units - VIEIRA, 1989) were calculated.

Seasonal variation in the density of S. cubensis was determined from the average monthly densities.

Fluctuations in water level were determined by use of a graduated measuring rod at the edge of the lake.

\section{RESULTS}

Figure 3 shows the average density, the standard deviation and the coefficient of deviation (CV) for sample units at 
different collection times. Average density varied between $114.56 \pm 192.48$ ind. $\mathrm{m}^{-2}$ on $89 / 11 / 14$ (12 sample units) to $308.00 \pm 174.24$ ind. $\mathrm{m}^{-2}$ on $90 / 5 / 17$ (4 sample units). The CV varied in range from $15.11 \%$ on $90 / 3 / 30$ ( 8 sample units) to $85.30 \%$ on $89 / 11 / 14$ (4 sample units). In general, along of the year the $\mathrm{CV}$ calculated is low.
Variances for averages are showed in Figure 4. Can be observed that there is a tendency of its diminution with increase of sampling units.

The average density of S. cubensis (fig. 5) displayed over the whole study period, a showed range of variation between $135.52 \pm 171.52$ ind. $\mathrm{m}^{-2}(89 / 11 / 14)$ and $270.88+196.00$
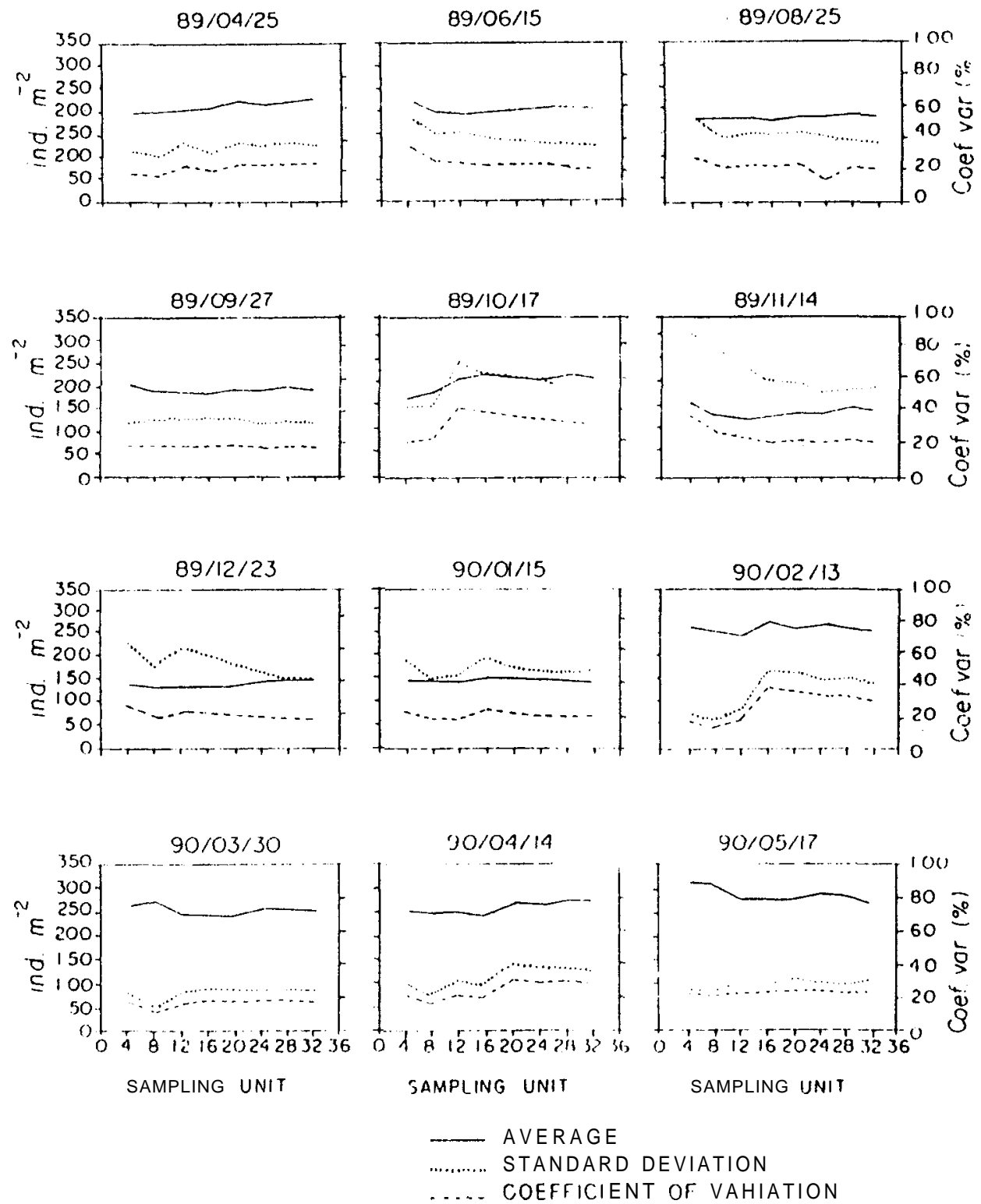

FIGURE 3. Average densities, standard deviations and coefficients of variation (coef. var. on different collecting d a for samble units of populations of S. cubensis. FIGURA ${ }^{3}$. Densidades medias, desviación standard y coeficientes (coef. var.) en días diferentes de recolección por unidad de muestras de la población de S. cutrensis. 
ind. $\mathrm{m}^{-2}(90 / 4 / 14)$, while the $\mathrm{CV}$ ranged from $24.22 \%$ to $52.80 \%$.

From April 1989 to January 1990 can be observed a tendency to diminution of density, with the smallest values from November 1989 to January 1990 (fig. 5). Later, occur a rise of S. cubensis density attaining highest values from February to May 1990.
The water level presented a marking variation, with peak in January 1990 (fig. 5)

\section{DISCUSSION}

DEL VISO et al. (1968), collecting macrophytes from plots of $1 \mathrm{~m}^{2}$ at 3 sites with 4 sample units per site, observed a
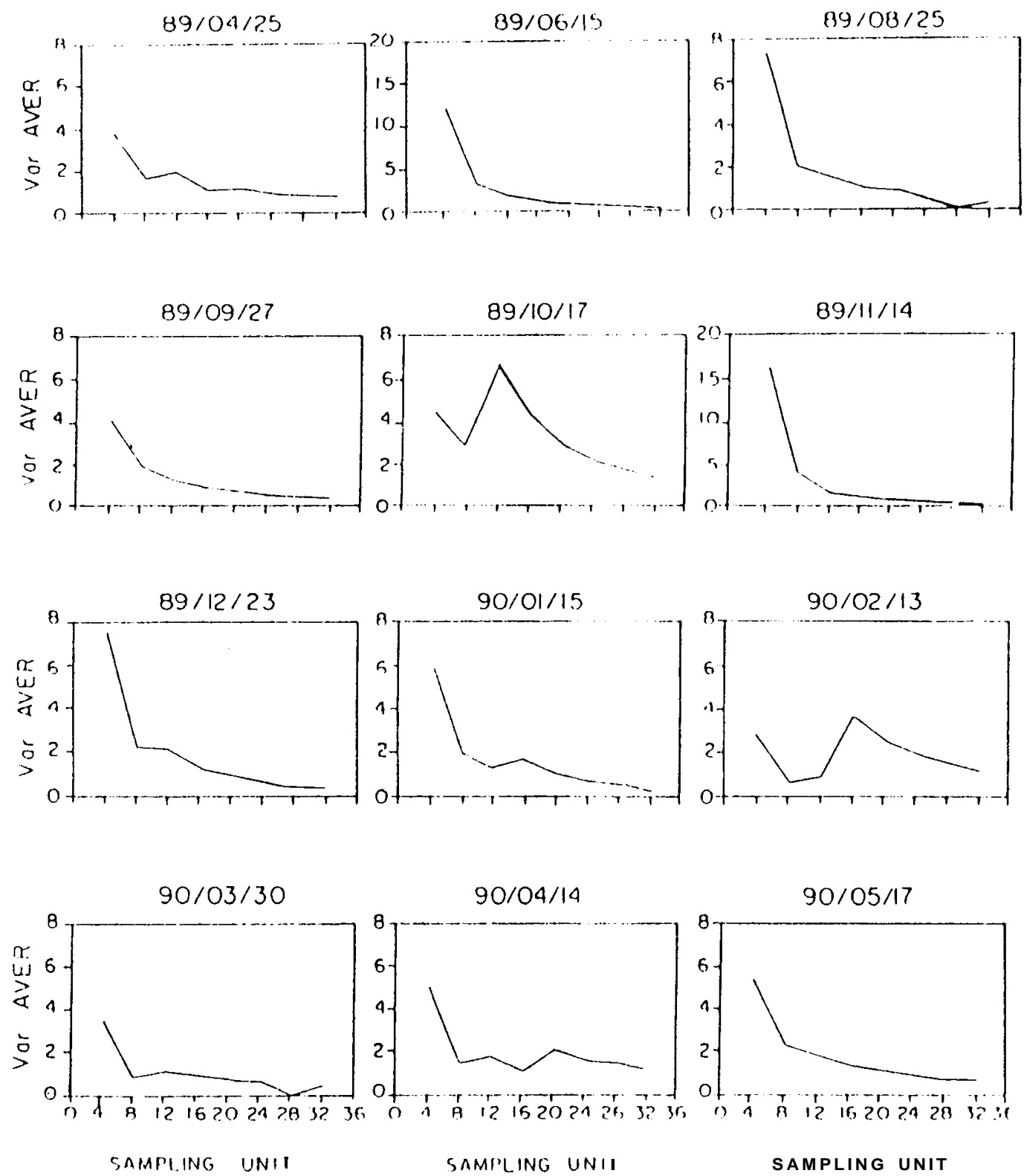

FIGURE 4. Variances for averages (var. aver.) on different collecting days for sample units of populations of S. cubensis

FIGURA 4. Diferencia en las varnaciones medias (var. med.) en días diferentes de recolección por unidad de muestras de la población de S. cubensis 


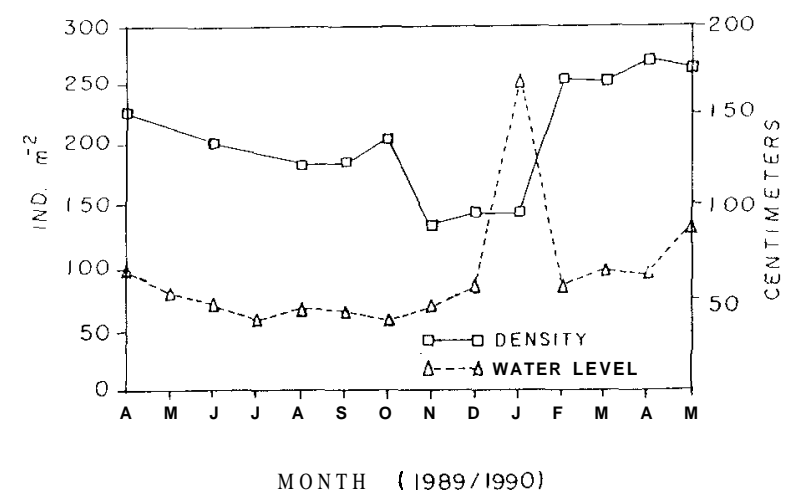

FIGURE 5. Seasonal differences in water level and average density of S. cubensis.

FIGURA 5. Diferencias estacionales en el nivel del agua y densidad media de S. cubensis.

greater coefficient of variation between sites (10.5\%) than between sample units $(6 \%)$. These authors believed that the greater variations is related to the lack of homogeneity in the plant cover rather than to the occurrence of errors in assessment of the sample units.

According to DOWNING \& ANDERSON (1985), care is needed in determination of the biomass of aquatic plants, since the pattern and distribution of the stands may lead to sampling errors. However, no general model has been proposed in relation to the expected variance in estimates of replicas for determination of biomass; the same is true for density, as observed in this work.

In ecological research it is convenient to analyze a proportion of a community, and to infer the results from the constituent populations. It is thus important to assess the number of sample units necessary to ensure satisfactory representation of the variable under consideration.

For example, samples represented by 10, 20, 30 etc. sample units, where the preceding units are contained within the following ones, display a tendency towards reduction in the respective variances of the average as the number of sample units increases (fig. 4). This suggests that the dispersion of sample averages among the population average diminishes, and shows approximation between them. However, by stabilization of the $\mathrm{S}^{2} / \mathrm{n}$ curve against the number of sample units (MATTEUCCI \& COLMA, 1982), inferences may be drawn as to the number of elements which the sample should contain for a satisfactory representation of density. In this work, the data suggest that the number of sample units is around 12 (fig. 4).

Given the large number of sample units involved, this technique is better employed for preliminary studies, through evaluation of the number of units necessary for determination of the biomass of macrophytes (POMPÊO \& MOSCHINI-CARLOS, 1995) and also of density, as showed in the present work.

There is no consensus as to the number of elements in the sample or to the size and form of the sampling mechanism in the study of vegetation (WESTLAKE, 1971; MATTEUCCI \& COLMA, 1982; ROBERTS et al., 1987; POMPÊO \& MOSCHINI-CARLOS, 1995) The problem becomes increasingly complex in function of the various groups of macrophytes - emergent, leaves floating, submerged and rooted, submerged and free-floating - largely due to the difficulties involved in applying the same method to such widely differing forms (ESTEVES, 1988). In general terms one should keep in mind the objectives of the work, the practical aspects of collecting in the field, the time needed for processing of the samples in the laboratory. and the costs.

On the period from April 1989 to May 1990, through to determination and follow up of the phenophases of S. cubensis in the Lagoa do Infernão, MOSCHINI-CARLOS et al. (1995) observed that the mean density of no fertiles individuals varied between 106 to 260 ind. $\mathrm{m}^{-2}$. The authors verified that from April 1989 to November 1989, occur a diminution of vegetative stadium density, later followed a increase with biggest values from February to May 1990. With relation to reproductive stadium, was observed a density variation in a range from 2.5 to 54 ind. $\mathrm{m}^{-2}$, with a maximum in October 1989. This manner, could be observed a synchrony, in the period of biggest density of no fertiles fractions, where observed smallest vegetative stadium density. The authors also observed biggest vegetative growth after flood occurrence in February 1990 (fig. 2).

The biomass of S. cubensis in the Lagoa do Infernão presented a range between from 1320.9 to $2476.0 \mathrm{gDW} . \mathrm{m}^{-2}$ (MOSCHINI-CARLOS et al., 1993). According to authors, the annual pattern in the $\mathrm{S}$. cubensis biomass variation is related to water level variation.

In this work, also was observed a great increase in density after the lake was flooded in January 1990. According to MITSCH \& GOSSELINK (1986) the supply of water and nutrients in oxbow lakes is related to the rise and fall of the water level in the adjoining river. According to JUNK (1984) the rapid growth and high rate of vegetative reproduction observed in macrophytes are related to a rise in water level and ensure rapid colonization of newly available areas. CAMAR GO \& ESTEVES (1996) verified that annual pattern of biomass variation and chemical composition of macrophyte Eichhornia azurea in the Lagoa do Mato, an oxbow lagoon of the Mogi-Guaçu River, neighbour to Lagoa do Infernão, is 
relationed to flood pulse. This one, causes an increase in nutrients contents in vegetal tissue. The authors discussed that the fertilization of lagoon in the period of rise water level, associated with other factors, determine a typical seasonal variation in the biomass and chemical composilion of the macrophytes. Studies carried out in Brazil also have shown that variation in water level is one of the principal factors responsible for alterations in the living biomass, detritus, and total biomass of macrophytes (PIEDADE et al, 1991; JUNK \& PIEDADE, 1993; CAMARGO \& ESTEVES, 1995a, b; POMPEO, 1996). Thus, the population density dynamics of $S$. cubensis, observed over one year in the Lagoa do Infernão, must thus be attributed to the cycles of flooding and drought which occur in the lake.

\section{REFERENCES}

BARBOUR, M.G., BURK, J.H. \& PITTS, W.D., 1987. Terrestrial plant ecology. The Benjamin Cummings. Menlo Park. 634 pp.

BEST, E.P.H., 1988. The phytosociological approach to the description and classification of aquatic macrophytic vegetation. In: Vegetation of inland waters (H. LIETH, ed.) 155-161. Klumer Academy. Dorbrecht.

CAMARGO, A.F.M. \& ESTEVES, F.A., 1995a. Biomass and productivity of aquatic macrophytes in Brazilian lacustrine ecosystems. In: Limnology in Brazil (J.G. TUNDISI, C.E.M. BICUDO \& T. MATSUMURA-TUNDISI, eds.) 137-149. ABC/SBL. Rio de Janeiro.

CAMARGO, A.F.M \& ESTEVES, F.A., 1995b. Influence of water level variation on fertilization of on oxbow lake of Rio Mogi-Guaçu, State of São Paulo, Brazil. Hydrobiologia, 299: 185-193.

CAMARGO, A.F.M \& ESTEVES, F.A., 1996. Influence of water level variation on biomass and chemical composition of the aquatic macrophyte Eichhornia azurea (Kunth) in an oxbow lake of the Rio Mogi-Guaçu (São Paulo, Brazil). Arch. Hydrobiol., 135(3): 423-432.

CAVALHEIRO, F., BALLESTER, M.V.R., KRUCHE, A.V., MELO, S.A., WAECHTER, J.T., DA SILVA, C.J., DIARIENZO, M.C., SUZUKI, M., BOZELLI, R., JESUS, T.P. \& SANTOS, J.E., 1990. Propostas preliminares referentes ao plano de zoneamento e manejo da Estação Ecologica do Jatai. Acta Limnol. Brasil., 3: 951 - 968.

COOK, C.D.K., GUT, B.J., RIX, E.M., SCHORELLER, J. \& SEITZ, M., 1974. Water plants of the world: a manual for the identification of the genera of freshwater macrophytes. Dr. W. Junk Publi. The Hague. 561 pp.
COUTINHO. M.E., 1989. Ecologia populacional de Eicchornia azurea (Kth) e sua participação na dinâmica da vegetação aquática da Lagoa do Infernão - SP. 145 pp. UFSCar. São Carlos. MSc Thesis.

DEL VISO, R.P., TUR, N.M.. MANTOVANI, V., 1968. Estimation de la biomassa de hidrofitos en cuencas isleñas del Parana medio. Physis, 28(76): 219-226.

DOWNING, J.A. \& ANDERSON, M.R., 1985. Estimating the standing biomass of aquatic macrophytes. Can. J. Fish. Aquat. Sci., 42: 1860-1869.

ESTEVES, F.A., 1988. Fundamentos de Limnologia. Interciência. Rio de Janeiro. 576 pp.

GREIG-SMITH, P., 1983. Quantitative plant ecology. Blackwell Scientific Publications. London. 359 pp.

HENRIQUES, R.P.B., ARAUJO, D.S.D., ESTEVES, A.F. \& FRANCO, A.C., 1988. Análise preliminar das comunidades de macrófitas aquáticas da lagoa Cabiunas. Acta Limnol. Brctsil., 2: 783-802.

JUNK, W.J., 1984. Ecology of the várzea, floodplain ot Amazonian white-water rivers. In: The Amazon: limnology and landscape ecology of a might tropical and its basin $(\mathrm{H}$. SIOLI, ed.) 216-243. Dr. W. Junk. Publi. Dorbrecht.

JUNK, W.J., BAYLEY, P.B. \& SPARKS, R.E., 1989. The flood pulse concept in river floodplain systems. Can. Spec. Publi. Aquat. Sci, 106: 110-127.

JUNK, W.J. \& PIEDADE, M.T.F., 1993. Biomass and primary-production of herbaceous plant communities in the Amazon floodplain. Hydrobiologia, 263: 155-162.

MATTEUCCI, S.D. \& COLMA, A., 1982. Metodologia para el estudio de la vegetacion. Secretaria General de la Organizacion de los Estados Americanos, Programa Regional de Desarrollo Cientifico y Tecnologico. Washington. 168 pp.

MITSCH, W.J. \& GOSSELINK, J.G., 1986. Wetlands. Van Nostrand Reinhold. New York. 539 pp.

MOSCHINI-CARLOS, V., 1991. Aspectos ecológicos da associação vegetal de Scirpus cubensis na Lagoa do Infernão - SP. 125 pp. UFSCar. São Carlos. MSc Thesis.

MOSCHINI-CARLOS, V., SOARES, J.J. \& POMPÊO, M.L.M.. 1993. Variação temporal da biomassa em uma comunidade vegetal aquática. Revta. Brasil. Biol., 53(3): 501-509.

MOSCHINI-CARLOS, V., POMPEO, M.L.M. \& SOARES, J.J., 1995. Fenologia de Scirpus cubensis Poepp. \& Kunth na Lagoa do Infernão (Estação Ecológica do Jatai, Luiz Antônio, SP). Acta Limnol. Brasil., 3: 1-9.

ODUM E.P., 1971. Fundamentals of ecology. W. B. Saunders. Philadelphia. 574 pp.

PIEDADE, M.T.F., JUNK, W.J. \& LONG, S.P., 1991. The productivity of the $\mathrm{C} 4$ grass Echinochloa polystachva on the 
Amazon floodplain. Ecology, 72(4): 1456-1463.

POMPEO, M.L.M. \& MOSCHINI-CARLOS, V., 1995. Zonação e biomassa das macrofitas aquáticas da Lagoa do Infernão (Brotas, SP), com ênfase na Utricularia gibba. Actn Limnol. Brasil., 7: 78-86.

POMPEO, M.L.M.. 1996. Ecologia de Echinochloa polystachya H.B.K. Hitchcock na represa de Jurumirim (zona de desembocadura do rio Paranapanema - SP). 150 pp. USP, São Carlos. Ph.D. Thesis.

ROBERTS, M.J., LONG, S.P., TIESZEN, L.L. \& BEADLE, C.L., 1987. Measurement of plant biomass and net primary production. In: Techniques in bioproductivity and photosynthesis (J. COOMBS, D.O. HALL, S.P. LONG \& J.M.O. SCURLOCK, eds.) 1-25. Pergamon Press Ltd.

SANTOS, J.E. \& MOZETO, A.A., 1992. Programa de análise de ecossistemas e monitoramento ambiental: Estação Ecológica do Jatai (Luiz Antônio, SP). Ecologia de áreas alagáveis da Planície de Inundação do Rio Mogi-Guaçu (Projeto Jatai). PPG-ERN/UFSCar. São Carlos. 60 pp.

TOLEDO FILHO, D.V., 1984. Composição florística e estrutura fitossociológica da vegetação de cerrado no município de Luiz Antônio (SP). 173 pp. UNICAMP, Campinas. MSc Thesis.

VIEIRA, S., 1989. Introdução à bioestatística. Campus Ltda. Rio de Janeiro. 296 pp.

WESTLAKE, D.F., 1971. Macrophytes. In: A manual on methods for measuring primary production in aquatic environments (R.A. VOLLENWEIDER, cd.) 25-32. Blackwell Scientific Publications. London. (IRP Handbook. 12). 